\title{
Pengaruh Model Pembelajaran Kooperatif Tipe Student Teams Achievement Divisions (STAD) terhadap Peningkatan Prestasi Belajar Siswa
}

\author{
Rizzaludin \\ Program Studi Pendidikan Sejarah, STKIP Yapis Dompu \\ E-mail: rizzaludinaziz@gmail.com
}

Article History: Received: 2022-01-11 || Revised: 2022-02-01 || Published: 2022-02-08

Sejarah Artikel : Diterima: 2022-01-11 || Direvisi: 2022-02-01 || Dipublikasi: 2022-02-08

\begin{abstract}
This research is an experimental type of research that aims to determine the effect of the cooperative learning model type student teams achievement divisions (STAD) on improving student learning achievement on the subject matter of systems and economic problems in the even semester of class X SMAN 2 Dompu in the 2020/2021 academic year. The population in this study were all students of X SMAN 2 Dompu for the academic year 2020/2021, totaling 33 people. Because the total population is less than 100 then all populations are used as research samples. In this study, the data analysis used was descriptive analysis. From the results of data analysis and discussion, it can be concluded that there is an effect of the cooperative learning model type student teams achievement divisions (STAD) on improving student learning achievement with basic material systems and economic problems in the even semester of class X SMAN 2 Dompu for the $2020 / 2021$ academic year, this is shown with a calculated $r_{\text {value }}$ greater than $r_{\text {table }}\left(r_{\text {count }} \geq r_{\text {table }}=0.615 \geq 0.344\right)$ with a very strong category level effect.
\end{abstract}

Keywords: Cooperatives, STAD, Learning Achievements.

\begin{abstract}
Abstrak
Penelitian ini adalah jenis penelitian eksperimen yang bertujuan untuk mengetahui Pengaruh Model Pembelajaran Kooperatif Tipe student teams achievement divisions (STAD) terhadap peningkatan Prestasi Belajar Peserta Didik Materi Pokok Sistem dan Permasalahan Ekonomi Semester Genap Kelas X SMAN 2 Dompu Tahun Ajaran 2020/2021. Populasi dalam penelitian ini adalah seluruh peserta didik X SMAN 2 Dompu Tahun Ajaran 2020/2021 yang berjumlah 33 orang. Karena jumlah populasi kurang dari 100 maka semua populasi dijadikan sampel penelitian. Dalam penelitian ini analisis data yang digunakan adalah analisis deskriptif. Dari hasil analisis data dan pembahasan dapat disimpulkan bahwa ada pengaruh model pembelajaran Kooperatif Tipe student teams achievement divisions (STAD) terhadap peningkatan Prestasi Belajar Peserta Didik Materi Pokok Sistem dan Permasalahan Ekonomi Semester Genap Kelas X SMAN 2 Dompu Tahun Ajaran 2020/2021, hal ini ditunjukkan dengan nilai $r_{\text {hitung }}$ lebih besar dari $r_{\text {tabel }}\left(r_{\text {hitung }} \geq r_{\text {tabel }}=\right.$ $0,615 \geq 0,344$ ) dengan tingkat kategori pengaruhnya sangat kuat.
\end{abstract}

Kata kunci: Kooperatif, STAD, Prestasi Belajar.

\section{PENDAHULUAN}

Dalam rangka pembangunan manusia Indonesia seutuhnya, pembangunan di bidang pendidikan merupakan sarana dan wahana yang sangat penting dan menentukan dalam pembinaan sumber daya manusia. Maka dari itu bidang pendidikan memerlukan perhatian yang sungguh-sungguh dari pemerintah, masyarakat pada umumnya dan para pengelola pendidikan pada khususnya. Terapan dari proses pendidikan tersebut adalah proses belajar mengajar yang kemudian dikenal dengan istilah proses pembelajaran. Proses pembelajaran adalah suatu proses yang rumit karena tidak sekedar menyerap informasi dari guru tetapi melibatkan berbagai kegiatan dan tindakan yang 
harus dilakukan untuk mendapatkan hasil belajar yang baik. Dalam proses pembelajaran terjadi hubungan timbal balik (interaksi) antara guru dengan siswa. Dalam interaksi tersebut guru berperan sebagai pengajar atau motivator dan fasilitator dalam belajar. Guru dituntut mampu menciptakan situasi pembelajaran yang kondusif, yaitu pembelajaran aktif, kreatif, inovatif, efektif dan menyenangkan dalam proses kegiatan pembelajaran.

Namun, berdasarkan hasil observasi awal peneliti, dalam proses pembelajaran pendidik secara aktif memberi pengetahuan kepada peserta didik yang pasif. Pendidik hanya bisa menuangkan apa yang diketahuinya ke dalam botol kosong yang siap menerimanya. Artinya, mereka mengajar dengan strategi ceramah dan mengharapkan peserta didik duduk, diam, dengar, catat, dan hafal. Kondisi pembelajaran yang demikian, masih mendominasi proses pembelajaran pada sebagian besar jenjang pendidikan. Guna mengatasi masalah tersebut dapat dilakukan dengan cara meningkatkan keikutsertaan peserta didik secara aktif dalam kegiatan proses belajar mengajar. Seperti dikemukakan Weha (2009: 189), bahwa perlu adanya kegiatan belajar mengajar sebagai pendorong peserta didik untuk aktif berpartisipasi. Dengan aktifnya peserta didik dalam kegiatan pembelajaran diharapkan hasil pembelajaran dan retensi peserta didik dapat meningkat dan kegiatan pembelajaran lebih bermakna. Berdasarkah hasil penelitian menunjukkan bahwa pembelajaran oleh rekan sebaya melalui pembelajaran kooperatif ternyata lebih efektif daripada pembelajaran oleh pengajar (Weha, 2009: 189).

Melalui pembelajaran kooperatif akan memberi kesempatan pada peserta didik untuk bekerja sama dengan sesama peserta didik dalam tugas-tugas yang terstruktur. Melalui pembelajaran kooperatif pula, seorang peserta didik akan menjadi sumber belajar bagi temannya yang lain. Weha (2009: 189), mengatakan bahwa pembelajaran kooperatif dikembangkan dengan dasar asumsi bahwa proses belajar akan lebih bermakna jika peserta didik dapat saling mengajari. Salah satu model pembelajaran kooperatif yang dapat meningkatkan prestasi peserta didik dalam pembelajaran ekonomi adalah model pembelajaran kooperatif tipe student teams-achievement divisions (STAD). Pembelajaran kooperatif tipe student teams achievement divisions (STAD) adalah pembelajaran dimana peserta didik ditempatkan dalam tim belajar beranggotakan 4-5 orang yang merupakan campuran menurut prestasi, jenis kelamin dan suku. Pendidik menyajikan pelajaran, dan kemudian peserta didik bekerja dalam tim mereka memastikan bahwa seluruh anggota tim telah menguasai pelajaran tersebut. Kemudian, seluruh peserta didik diberikan tes tentang materi tersebut, pada saat tes ini mereka tidak diperbolehkan saling membantu (Nur, 2000: 26).

Pembelajaran kooperatif tipe student teams-achievement divisions (STAD) merupaka tipe pembelajaran yang terdiri atas lima komponen umata. Kelima komponen ini sangat berpengaruh terhadap keberhasilan belajar peserta didik dalam kegitan belajar mengajar. Adapun kelima komponen yang dimaksud adalah presentasi kelas, tim, kuis, skor kemajuan individu, dan rekognisi tim. Melalui lima komponen utama pembelajaran kooperatif tipe student teams-achievemen divisions (STAD) kegiata belajar mengajar yang dilakukan oleh pendidik dan peserta didik di kelas dapat ditingkatkan. Hal ini dapat dibuktikan dengan melihat bagaiamana keaktifan peserta didik dalam mempelajari materi yang diberikan oleh pendidik di dalam kelas. Disamping itu, pendidik juga dapat memberikan kuis kepada peserta didik untuk mengukur seberapa jauh penguasaan peserta didik terhadap materi yang telah dipelarinya. Dengan menggunakan dua pendekatan di atas, maka pendidik dapat menarik kesimpulan bahwa pemerapan model pembelajran kooperatif tipe student teams-achievemen divisions (STAD) dapat meningkatkan prestasi belajar peserta didik..

\section{METODE PENELITIAN}

Penelitian ini dilaksanakan di SMAN 2 Dompu tahun pelajaran 2020/2021. Jenis penelitian yang digunakan yaitu penelitian eksperimen yang terdiri dari pemberian pre-test dan post-test. Dalam rancangan penelitian ini digunakan satu kelompok subjek. Pertama-tama dilakukan pengukuran, 
lalu dikenakan perlakuan untuk jangka waktu tertentu, kemudian dilakukan pengukuran kedua kalinya (Suryabrata, 2011: 100). Rancangan ini dapat disajiikan pada pada tabel berikut.

Tabel 1. Rancangan eksperimen model One Group Pre-test-Posstest Design

\begin{tabular}{clc}
\hline $\begin{array}{c}\text { Data awal } \\
\text { Pre test }(\mathbf{X})\end{array}$ & \multicolumn{1}{c}{ Perlakuan } & Data akhir \\
\cline { 2 - 3 } & $\begin{array}{l}\text { Menggunakan Metode kooperatif tipe Student Teams } \\
\text { Ychievement Divisions (STAD) }\end{array}$ & Ya \\
\hline
\end{tabular}

Teknik pengumpulan data yang dilakukan dengan teknik observasi dan pemberian tes. Data yang diperoleh ialah data primer yang bersumber dari siswa kelas X SMAN 2 Dompu. Teknik analisis yang digunakan adalah anasis deskriptif.

\section{HASIL DAN PEMBAHASAN}

\section{A. Data Hasil Penelitian}

Pada bagian ini akan deskripsikan tentang data hasil pelaksanaan penelitian untuk mengetahui ada tidaknya pengaruh metode pembelajaran kooperatif tipe student teamsachievement divisions (STAD) terhadap prestasi belajar peserta didik kelas X SMAN 2 Dompu pada pokok bahasan masalah eokonomi dan sistem ekonomi semester ganjil Tahun Pelajaran 2020/2021. Data penelitian ini adalah data kualitatif yang ditransformasikan berdasarkan bobot skor yang telah ditetapkan menjadi data kuantitatif, yakni satu, dua tiga dan empat. Data ini merupakan data kuantintatif yang selanjutnya dianalisis dengan statistik deskriptif. Sampel dalam penelitian adalah semua peserta didik kelas X SMAN 2 Dompu yang terdiri dari satu kelas sebanyak 33 orang. Adapun rincian pelaksanaan hasil penelitian dapat diuraikan sebagai berikut:

1. Data Prestasi Belajar

a. Data Pre-test

Pre-tes dilakukan untuk melihat sejauh mana tingkat prestasi belajar peserta didik sebelum menerapkan metode pembelajaran kooperatif tipe student achievement divisions (STAD). Data hasil pre-test secara ringkasnya dapat disjikan pada tabel berikut:

Tabel 2. Ringkasan Hasil Pre-Test Peserta Didik Kelas X SMAN 2 Dompu

\begin{tabular}{ll}
\hline \multicolumn{1}{c}{ Keterangan } & \multicolumn{1}{c}{ Hasil } \\
\hline Nilai Rata-rata kelas $(\bar{X})$ & 54.84 \\
\hline Nilai tertinggi & 70 \\
\hline Nilai terendah & 40 \\
\hline Jumlah peserta didik yang memenuhi KKM & 4 orang \\
\hline Jumlah peserta didik yang tidak memenuhi KKM & 29 orang \\
\hline
\end{tabular}

Berdasarkan tabel diatas menunjukkan bahwa prestasi belajar peserta didik sebelum diterapkan metode pembelajaran kooperatif tipe student teams-achiavement divisions (STAD) banyak yang belum memenuhi kriteria kentuntasan Minimal (KKM) yang ditentukan oleh sekolah yaitu jumlah peserta didik yang memperoleh nilai kurang dari 65. Dari 33 orang yang mengikuti pre-tes hanya 4 orang yang mampu memenuhi KKM dan 29 orang lainnya belum mampu memenuhi KKM dengan nilai rata-rata kelas yang dicapai peserta didik sebesar 54.84 dan nilai tertinggi maupun nilai terendah yang mampu dicapai peserta didik pada pre-test ini masing-masing sebesar 70 dan 40 . 
b. Data Hasil Post Test

Post test dilakukan setelah menggunakan metode pembelajaran kooperatif tipe student tiams-achievement divisions (STAD). Ringkasan data hasil post-test dapat disajikan pada tabel 3.2 berikut ini.

Tabel 3. Ringkasan Hasil Post Test Peserta Didik Kelas X SMAN 2 Dompu

\begin{tabular}{ll}
\hline \multicolumn{1}{c}{ Keterangan } & \multicolumn{1}{c}{ Hasil } \\
\hline Nilai Rata-rata kelas $(\bar{X})$ & 91.51 \\
\hline Nilai tertinggi & 100 \\
\hline Nilai terendah & 79 \\
\hline Jumlah peserta didik yang memenuhi KKM & 33 orang \\
\hline Jumlah peserta didik yang tidak memenuhi KKM & 0 orang \\
\hline
\end{tabular}

Berdasarkan tabel diatas, menunjukkan sebanyak 33 orang yang mengikuti post test semuanya telah mencapai KKM dengan nilai rata-rata kelas yang dicapai peserta didik pada saat post test ini sebesar 91.51 dan nilai tertinggi maupun nilai terendah yang mampu dicapai peserta didik masing-masing sebesar 100 dan 79.

\section{Pengujian Hipotesis}

Berikut ini akan dideskripsikan hasil analisis data untuk menguji hipotesis: Ha (Ada pengaruh metode pembelajaran kooperatif tipe student tiams-achievement divisions (STAD) terhadap peningkatan prestasi belajar peserta didik kelas X SMAN 2 Dompu pada pokok bahasan masalah ekonomi dan sistem ekonomi semester ganjil tahun pelajaran 2020/2021, dan Ho (tidak ada pengaruh metode pembelajaran kooperatif tipe student tiamsachievement divisions (STAD) terhadap peningkatan prestasi belajar peserta didik kelas $\mathrm{X}$ SMAN 2 Dompu pada pokok bahasan masalah ekonomi dan sistem ekonomi semester ganjil tahun pelajaran 2020/2021. Pada proses pengujian hipotesis yang dilakukan, diperoleh Nilai $r$ hitung, yang selanjutnya dibandingkan dengan nilai $r_{\text {tabel. }}$ Nilai $r$ tabel untuk $N=33$ pada taraf signifikan $5 \%$ adalah $0,344\left(\mathrm{r}_{\text {tabel }}=0,344\right)$. Berdasarkan perhitungan tersebut, ternyata $r_{\text {hitung }}$ lebih besar dari $r_{\text {tabel }}(0,615 \geq 0,344)$. Dengan demikian Ho ditolak dan Ha diterima. Jadi, kesimpulannya ada pengaruh metode pembelajaran kooperatif tipe student teams-achievement divisions (STAD) terhadap peningkatan prestasi belajar peserta didik kelas X SMAN 2 Dompu pokok bahasan masalah ekonomi dan sistem ekonomi semester ganjil tahun pelajaran 2020/2021 dengan koefesien korelasi yang diperoleh sebesar 0,615 dan tergolong kuat.

\section{B. Pembahasan}

Berdasarkan hasil analisis data di atas dapat diketahui bahwa metode pembelajaran kooperatif tipe student teams-achievement divisions (STAD) memiliki pengaruh yang signifikan terhadap peningkatan prestasi belajar peserta didik kelas X SMAN 2 Dompu pokok bahasan masalah ekonomi dan sistem semester ganjil tahun pelajaran 2020/2021. Indikatornya, berdasarkan hasil analisis data melalui uji statistik deskriptif di atas menunjukkan nilai $\mathrm{r}_{\text {hitung }} \geq$ $r_{\text {tabel }}=0,616 \geq 0,344$. Nilai kooefesien korelasi sebesar 0,615 juga menunjukkan bahwa antara metode pembelajaran kooperatif tipe student teams-achievement divisions (STAD) dengan peningkatan prestasi belajar peserta didik kelas X SMAN 2 Dompu memiliki pengaruh yang sangat kuat, bukti lain yang menunjukkan adanya pengaruh metode pembelajaran kooperatif tipe student teams-achievement divisions (STAD) terhadap peningkatan prestasi belajar peserta didik kelas X SMAN 2 Dompu semester ganjil tahun pelajaran 2020/2021 dapat dilihat dari peningkatan nilai rata-rata kelas yang diperoleh peserta didik melalui hasil pre-test dan post 
test. Pada saat pre-test nilai rata-rata yang diperoleh peserta didik sebesar 54.84, kemudian nilai rata-rata kelas yang dicapai peserta didik pada saat postest meningkat menjadi 91.51

Dari uraian pembahasan di atas membuktikan bahwa ada pengaruh metode pembelajaran kooperatif tipe student teams-achievement divisions (STAD) terhadap peningkatan prestasi belajar peserta didik kelas X SMAN 2 Dompu pokok bahasan masalah ekonomi dan sistem semester ganjil tahun pelajaran 2020/2021.

\section{SIMPULAN DAN SARAN}

\section{A. Simpulan}

Berdasarkan hasil analisis data dan pembahasan dapat disimpulkan bahwa ada pengaruh metode pembelajaran kooperatif tipe student teams-achievement divisions (STAD) terhadap peningkatkan prestasi belajar peserta didik kelas X SMAN 2 Dompu pada pokok bahasan masalah ekonomi dan sistem ekonomi semester ganjil Tahun pembejaran 2020/2021, hal ini ditunjukkan dengan nilai $r_{\text {hitung }}$ lebih besar dari $r_{\text {tabel }}\left(r_{\text {hitung }} \geq r_{\text {tabel }}=0,615 \geq 0,344\right)$ dengan tingkat kategori pengaruhnya sangat kuat.

\section{B. Saran}

Setelah memperoleh kesimpulan maka peneliti dapat memberikan seran sebagai berikut: a) Pendidik diharapkan dapat menjadikan penggunaan model pembelajaran kooperatif tipe student teams-achivement divisions (STAD) sebagai alternatif yang tepat dalam kegiatan belajar mengajar, dan b) Peseta didik diharapkan dapat menyesuaikan diri dengan tujuan pembelajaran yang aktif dan efisien sehingga dapat memperoleh prestasi yang baik.

\section{DAFTAR RUJUKAN}

Arifin, A. (2003). Memahami Paradigma Baru Pendidikan Nasional Dalam Undang-Undang SISIDIKNAS. Jakarta, Ditjen Kelembagaan Agama Islam Depag.

Arifin, A., Sugerman, S., \& Amin, M. (2021). Respon Guru Tentang Pelanggaran yang dilakukan Siswa (Studi Kasus di SDN 10 Pajo). Ainara Journal (Jurnal Penelitian Dan PKM Bidang Ilmu Pendidikan), 2(3), 193-205. https://doi.org/10.54371/ainj.v2i3.81

Arikunto, Suharsimi. 2009. Manajemen Penelitian. Jakarta : Rineka Cipta.

Isjono. (2009). Pembelajaran Kooperatif Meningkatkan Kecerdasan Komunikasi Antar Peserta Didik. Yogyakarta: Pustaka Pelajar

Kusumawati Heni. (2010). Penerapan Model Pembelajaran Kooperatif Tipe Pertukaran Kelompok dalam Meningkatkan Prestasi Belajar Pokok Bahasan Perusahaan dan Badan Usaha pada Siswa Kelas VII SMP NW Mataram Semester Ganjil Tahun Ajaran 2010/2011. Mataram: Universitas Nahdlatul Wathan Mataram.

Nasution, (2009). Metode research (Penelitian Ilmiah). Jakarta : Bumi Aksara

Riyanto, (2007). Metodologi Penelitian Pendidikan Kualitatif dan Kuantitatif. Surabaya: Unesa University Press

Supriyono. (2009). Cooperatif Learning Teori dan Aplikasi PAIKEM. Yogyakarta: Pustaka Pelajar.

Taufik, Erwin, \& Husnul Khatimah. (2020). Pengembangan Perangkat Pembelajaran Model CIRC pada Mata Kuliah Apresiasi Sastra "Mantra Mbojo" untuk Melatih Kemampuan Berpikir Kreatif Mahasiswa. JIIP - Jurnal Ilmiah Ilmu Pendidikan,3(3), 635-641. Retrieved from http://jiip.stkipyapisdompu.ac.id/jiip/index.php/JIIP/article/view/171 
Taufik, T., Imansyah, M. N., \& Yulianti, E. (2021). Efektivitas Penggunaan Buku Ajar Sastra Lisan Suku Mbojo Berorientasi pada Model CIRC untuk Matakuliah Apresiasi Sastra. Jurnal Inovasi, Evaluasi dan Pengembangan Pembelajaran (JIEPP), 1(2), 41-45. https://doi.org/10.54371/jiepp.v1i2.104

Trianto. (2007). Model-Model Pembelajaran Inovatif Berorientasi Konstruktivistik. Jakarta: Perpustakaan Nasional 